\title{
miR-143 over-expression reduces the growth of xenograft tumors from colon carcinoma cells
}

\author{
Pedro M Borralho ${ }^{1 *}$, Sofia Gomes ${ }^{1}$, Raquel T Lima ${ }^{2,3}$, Rui E Castro ${ }^{1}$, Maria H Vasconcelos ${ }^{2,3}$, Cecília MP Rodrigues ${ }^{1}$ \\ From 16th International Charles Heidelberger Symposium on Cancer Research \\ Coimbra, Portugal. 26-28 September 2010
}

We have previously shown that miR-143 is downregulated in colorectal cancer and that miR-143 overexpression in HCT116 cells increases sensitivity to 5 -fluorouracil, reduces cell viability and increases apoptosis in vitro. In the present study, we evaluated the role of miR-143 over-expression on HCT116 xenograft tumor growth in nude mice. HCT116 cells with stable miR-143 over-expression (over-143) and control (empty) cells were injected s.c. into the backs of nude mice, and tumor growth was evaluated. Tumors arose approximately 14 days later, and the experiment was ended 40 days after injection. miR-143 was confirmed to be significantly over-expressed in over-143versusempty xenografts, by Taqman real-time PCR. Over-143 xenografts displayed slower tumor growth compared to empty xenografts, with significantly smaller tumor volumes, from 23 until 40 days in vivo $(p<0.05)$, with final volumes of $928 \pm 338$ and $2312 \pm 387 \mathrm{~mm}^{3}$, respectively. Evaluation of apoptotic proteins showed that over-143versusempty xenografts, display reduced Bcl-2 expression, and increased caspase- 3 activation and PARP cleavage $(p<0.05)$. In addition, the incidence of apoptotic cells, assessed by TUNEL, was increased in over-143versusempty xenografts. Therefore, our results suggest that the reduced tumor volume may, in part, be due to increased miR-143-induced apoptosis. Collectively, our results reinforce the relevance of miR-143 in colorectal cancer, suggesting an important role in the control of in vivo tumor progression. This further expands its anti-proliferative, pro-apoptotic and chemosensitizer role that we have previously demonstrated in vitro.

\footnotetext{
* Correspondence: borralho@ff.ul.pt

${ }^{1}$ Research Institute for Medicines and Pharmaceutical Sciences (iMed.UL),

Faculty of Pharmacy, University of Lisbon, Lisbon, Portugal

Full list of author information is available at the end of the article
}

Acknowledgements

This work was supported by PTDC/SAU-GMG/099162/2008, FCT, Portugal.

\section{Author details}

${ }^{1}$ Research Institute for Medicines and Pharmaceutical Sciences (iMed.UL), Faculty of Pharmacy, University of Lisbon, Lisbon, Portugal. ' IPATIMUP, Institute of Molecular Pathology and Immunology of the University of Porto, Porto, Portugal. ${ }^{3}$ Department of Biological Sciences, Faculty of Pharmacy, University of Porto, Porto, Portugal.

Published: 24 September 2010

\section{doi:}

Cite this article as: Borralho et al:: miR-143 over-expression reduces the growth of xenograft tumors from colon carcinoma cells. BMC Proceedings 2010 4(Suppl 2):P59.
Submit your next manuscript to BioMed Central and take full advantage of:

- Convenient online submission

- Thorough peer review

- No space constraints or color figure charges

- Immediate publication on acceptance

- Inclusion in PubMed, CAS, Scopus and Google Scholar

- Research which is freely available for redistribution

Submit your manuscript at www.biomedcentral.com/submit
Biomed Central 